\title{
Paul Engle: A Checklist
}

The checklist which follows outlines the publishing career of a man who has been near the center of the American literary landscapeas poet, teacher, and editor-for more than thirty years. His publications as listed actually cover forty-one years. The work of the first ten years, however, reflects for the most part a chrysalis time of seeking a style. It was then, from the late twenties to the mid-thirties, that the intensely romantic, brilliant boy from Coe College emerged as a poet and went on to his state university to earn one of the first graduate degrees in creative writing ever given. After that, in 1932, his Iowa master's thesis was selected as a volume for the Yale Series of Younger Poets. In the meantime he had moved on for further study, first at Columbia University, and then at Oxford on a Rhodes Scholarship.

Paul Engle's emergence as a national literary phenomenon, however, can be dated from 1934, the year his first commercially published book of poetry, American Song, appeared. Stephen Vincent Benét said kind words about it, J. Donald Adams reviewed it enthusiastically on the front page of the New York Times Book Review, and the New York Herald Tribune listed it for some weeks as a best seller. Engle once told me that he was in Switzerland when first news of the book's success reached him. He became a young man on two mountaintops, the figurative one much more important than the literal one, and just as beautiful.

After returning to Iowa, he became a teacher in The University of lowa writing program and in 1942 was appointed director of the program, in which capacity he has continued until the present year. He has become famous for his ability to attract promising young writers, just

\footnotetext{
"Grateful acknowledgment is made to Ada M. Stoflet, Reference Librarian, The University of Iowa Libraries, for generous help in compiling this checklist.
} 
as the proverbial honey attracts the proverbial bees. In the process, a great many of the American poets, novelists, and short story writers who have been taken seriously during the past three and a half decades have passed through the Iowa workshops supervised by Paul Engle, either as students or teachers, or even, occasionally, as both.

Meanwhile, Engle has continued to write prolifically. As the checklist shows, his work has appeared in print continuously and in an enormous variety of places. I can think of no other living poet, for instance, who has been represented in so many different kinds of periodicals, from the smallest and most evanescent as well as the most enduring and prestigious of the "little" magazines, to some national periodicals with the widest and largest circulation. He has also published prose in widely distributed travel, popular history, and women's magazines, in addition to articles in professional and educational journals. And the checklist does not include, because of limited space, the dozens of book reviews which Engle has written for such newspapers as the Chicago Tribune, the New York Times, and the late New York Herald Tribune.

Besides the first impression of publishing scope, the checklist outlines the wide variety in Paul Engle's writing. For not only does his work show a great deal of lyric poetry, which forms the largest segment in the listings in both books and magazines, but it also reveals such intriguing variations as a full-length libretto, a novel, and a variegated group of essays. The diversity in that essay-writing has been rather startling: critical articles, descriptions of regional culture, explanations of the Iowa writers workshops, general educational statements, and memoirs are the more important prose areas Engle has occasionally explored.

So all during the time he has been a busy teacher and literary administrator, Paul Engle has shown a consistent ability to create good poems and to produce good prose. Doing this while constantly helping other, younger writers to get along in the highly competitive, wearing profession of letters, has been, I think, an amazing achievement.

\section{BOOKS}

WORN EARTH. New Haven: Yale University Press, 1932. [vi] 7-51p. $19 \% \mathrm{~cm}$. (The Yale Series of Younger Poets, XXXI) Also London: Humphrey Milford, Oxford University Press, 1932.

36 poems.

Dedication: To My Mother and Father and to Mr. and Mrs. L. A. Brewer. AMERICAN SONG; A Book of Poems. Garden City, New York: Double- 
day, Doran \& Company, Inc., 1934. [xviii] 3-102p. 191/2 $\mathrm{cm}$. Also London: Jonathan Cape, 1935. 112p.

30 poems.

Dedication: For Stephen and Rosemary [Benét].

BREAK THE HEART'S ANGER. Garden City, New York: Doubleday, Doran \& Company, Inc., 1936. [xii] 3-195p. $24 \mathrm{~cm}$. Also London: Jonathan Cape, 1936.

16 poems.

Dedication: [An 80-line poem to America].

CORN. New York: Doubleday, Doran \& Company, Inc., 1939. [x] 11-105p. $22 \mathrm{~cm}$. At head of title: A book of poems.

20 poems.

Dedication: To Mary who knows that the living is all, and the writing but a little thing.

[Awarded the Johnson Brigham Plaque by the Iowa Library Association ... 1940.]

ALWAYS THE LAND. New York: Random House, 1941. [viii] 326p. $21 \mathrm{~cm}$. Also Toronto: The Macmillan Company of Canada, 1941.

Novel.

Dedication: To Chuck and Jim Hearst, good farmers, good friends.

WEST OF MIDNIGHT. New York: Random House, 1941. [x] 11-96p. 23/2cm. Also Toronto: The Macmillan Company of Canada, 1941.

50 poems.

Dedication: To Albert and Bertha Johnson Friends in the West.

[Awarded $\$ 1,000$ by Friends of American Writers, Chicago.]

AMERICAN CHILD; A Sonnet Sequence. New York: Random House, 1945. [x] 3-66p. 19cm. Also Toronto: Random House of Canada, 1945. 64 poems.

Dedication: For Margaret Stoddard.

THE WORD OF LOVE. New York: Random House, 1951. [viii] 39p. $25 \mathrm{~cm}$. Also Toronto: Random House of Canada, 1951.

23 poems.

Dedication: To Mary who lived it.

AMERICAN CHILD; Sonnets for My Daughters, with Thirty-six New

Poems. New York: The Dial Press, 1956. [x] 3-102p. 19\%cm.

100 poems.

Dedication: For Margaret Stoddard

The second time this book for you-

All the old and all the new-

Because you understood the wild

Wonder of the human child,

Because you found no joy above

Mortal child from mortal love,

Because for all these years you knew

How life and child and sonnets grew. 
POEMS IN PRAISE. New York: Random House, 1959. [xvi] 3-97p. $23 \frac{1}{2} \mathrm{~cm}$.

30 poems.

Dedication: To A. and M. [a 12-line poem follows].

PRAIRIE CHRISTMAS. New York, London and Toronto: Longmans, Green and Company, 1960. [x] 51p. 22cm. Also with imprint: New York, McKay [1962].

5 essays and poem, A Christmas Child.

GOLDEN CHILD; A Christmas Opera, by Philip Bezanson. Libretto by Paul Engle. Telecast: December 16, 1960. New York: Compass Productions, 1960. (Television script; at head of title: Hallmark Hall of Fame.)

-; A Libretto by Paul Engle for an opera composed bv Philip Bezanson. With photographs from the telecast premiere on the Hallmark Hall of Fame. Kansas City, Missouri: Hallmark Cards, 1960. [viii] 7-61p.

-; Illustrated by Leonard Everett Fisher. New York: E. P. Dutton \& Company, 1962. [x] 11-127p. 21/1/2cm. Also Toronto \& Vancouver: Clarke, Irwin \& Company, Limited, 1962.

Children's Book.

Dedication: To A.H.M. who knew this child from the beginning.

SONG CYCLE, THE WORD OF LOVE. By Philip Bezanson, text by Paul Engle. (Composers facsimile edition.) New York: American Composers Alliance, 1962. 30p. $32 \mathrm{~cm}$.

WHO'S AFRAID? Illustrated by Ray Prohaska. New York: The CrowellCollier Press, 1963. [iii] 4-63p. 29\% $\%_{2} \mathrm{~cm}$. (A Modern Masters Book for Children.)

AN OLD FASHIONED CHRISTMAS. Illustrated by Eleanor Pownall Simmons. New York: The Dial Press, 1964. [xii] 13-96p. $21 \mathrm{~cm}$.

12 poems and 12 sketches.

Dedication: This book about the most special day in the vear is dedicated to Pauline V. Moore, M.D., of Iowa City, who dedicates herself every day of the year.

A WOMAN UNASHAMED AND OTHER POEMS. New York: Random House, 1965. [xiv] 3-109p. 22cm.

69 poems.

Dedication: To my lifelong friends and neighbors, Owen and Leone Elliott, Marvin and Winifred Cone, of Cedar Rapids, Iowa, who have also been lifelong friends of the arts.

BROCHURES, PAMPHLETS, RECORDINGS, ETC.

Poetry in a Machine Age. Reprinted for private circulation from The English Journal, Vol. XXXVI (June, 1937) (Essay; 11p.)

Our Human Strength. Reprinted from the December, 1939 issue of Poetry, Vol. LV. (7 poems; 7p.) 
New Englanders . . C Christmas 1940. Muscatine, lowa: Privately printed in an edition of 150 copies by Carroll Coleman at The Prairie Press, 1940. (5 sonnets; 10p.) Half title: Five Sonnets.

America 1941: Seven Poems. Reprinted from the September, 1941 issue of Poetry, Vol. LVIII, 9p.

Robert Frost: A Discussion by Alvan Ryan, Paul Engle and Charles Foster. [Phonodisc] Iowa City, Iowa: Radio Station WSUI [1942?] (Instantaneous recording, $331 / 3$ r.p.m., plays from inside out.) One in a series of radio programs entitled "The American Heritage" presented by radio station WSUI, and conducted by Professor Charles Howell Foster.

Songs for These States. Reprinted from the March, 1943 Step Ladder. (1 poem; 1p.) "Winner of $\$ 100$ prize, Patriotic Song Contest."

West of Midnight, and Other Poems. [Phonodisc recording, read by Horace Braham.] New York: American Foundation for the Blind, Inc., 1943. (Album of three records which also includes selections from Rupert Brooke, Omar Khayyam, and J. Thoburn.)

American Child ... Christmas 1944. Muscatine, Iowa: Privately printed in an edition of 350 copies by Carroll Coleman at The Prairie Press, 1944. (11 sonnets; 16p. including a profile drawing of Mary Engle, age 4, by Marvin Cone.)

The Bones of the Buffalo. [n.p.: 1944] (1 poem; 1p. broadside.) First prize, Forum poetry contest.

A Christmas Child. [n.p.: n.d.] (1 poem; 1p. broadside.)

Paul Engle Reading His Own Poems. [Phonodisc] Cambridge, Mass.: Harvard Film Service, 1944. (Harvard Vocarium Records, P-1068.)

For the Midwestern Dead, Christmas: MCMXLV. Iowa City, Iowa: [Prairie Press, 1945.] (4 sonnets; lp. broadside.)

Christmas 1946. n.p. (1 poem; 1p. broadside.) Sonnet beginning "Grabbing the earth as it falls away from us."

Paul Engle Reading His Own Poems: "West of Midnight," "Pair," "Fisherman," "Ralph Waldo Emerson," "Conclusion of Corn." [12-inch phonodisc, 2 sides, 78 r.p.m.] Washington: The Library of Congress Recording Laboratory [1946?]. (Twentieth Century Poetry in English. Record P6.) "Reissued from the Harvard Vocarium Recording" and accompanied by a leaflet containing the texts of the poems read, a biographical sketch, and a selected bibliography. Reissued on $331 / 3$ records in 1954.

Speaking of You Is the Denial of Speech. [20-line poem appearing on a Christmas card.] Iowa City, Iowa: The Prairie Press, 1947 (350 copies.) American Child II . . Christmas 1955. [Iowa City: The Prairie Press, 1955]

(3 sonnets; 4p.: Preprint from American Child, 1956.)

Arden-America; Averell Harriman. Iowa City, Iowa: Privately printed by Carroll Coleman at The Prairie Press, 1955. (2 sonnets; 2p.) 
A Name. [Iowa City, Iowa: The Prairie Press, 1955] (1 sonnet; 1p. broadside.)

Book and Child. Three Sonnets, printed for his and his family's friends, Christmas 1956. 4p. With an engraving on copper by Katharine Hefner. ("These sonnets first appeared in the New York Times.") Iowa City, Iowa: The Cummington Press, 1956.

The Child. [8-line poem appearing inside a Hallmark Christmas card, n.d. On cover: colored reproduction of a detail from El Greco's The Nativity, above the caption "A Blessed Christmas."]

For the Iowa Dead. [Iowa City] State University of Iowa, 1956. (22 sonnets; $24 \mathrm{p}$.

Three Sonnets for Colette. Reprinted from January Number of The Sewanee Review, Vol. LXIV, 1956. 3p.

Paul Engle Reading His Poems With Commentary in the Coolidge Auditorium, March 11, 1957. [Taped recording] [Washington: Library of Congress Recording Laboratory, Archive of Recorded Poetry and Literature, 1957] (Library Work Order 2550)

An Old Palestinian Donkey. Reprinted from Better Homes and Gardens (April, 1958). (1 poem; 1p. broadside.)

Robert Frost. Iowa City, Iowa: Typographic Laboratory, School of Journalism, State University of Iowa, 1959. "Three thousand copies distributed by the State University of Iowa Library on the occasion of Mr. Frost's visit to the University, April 13, 1959, during National Library Week." (1 poem; 4p.) Reprinted in The Des Moines Register (April 25, 1959), 4.

Easter. Reprinted from the April 1960 Better Homes and Gardens. (1 poem; Ip. broadside.)

Old Fashioned Christmas. Special edition. (Illustrated) Des Moines, Iowa: The Register and Tribune Syndicate, 1960. 48p. ("This booklet contains a complete reprint of the series of articles published in newspapers under the same title.")

Baldwin Maxwell Beguiled. [Sonnet] in A Dinner Celebrating "Studies in English Drama," a volume edited by Charles Woods and Curt Zimansky and presented to Baldwin Maxwell ... . [on December 15, 1961]. Iowa City, Iowa: [Typographic Laboratory] 1961. (The sonnet appears on page 3 of this 4 -page leaflet.)

The Program in Creative Writing. Iowa City, Iowa. The University of Iowa [1964] cover title, unpaged [32p. unsigned] Illustrated.

Poetry: The World's Voice. [A 24-minute $16 \mathrm{~mm}$. color film with Paul Engle as narrator; readings of 19 poems in 17 languages. Iowa City, Iowa: Produced by The University of Iowa Motion Picture Unit, Audiovisual Department, 1965] First shown January 20, 1965, at Shambaugh Auditorium, The University of Iowa Library. A leaflet concerning this film, including "a few notes by Paul Engle," was issued by The University of Iowa Division of Extension and University Services. 


\section{CONTRIBUTIONS TO PERIODICALS AND NEWSPAPERS}

\section{Poems}

1925

“Trains," The Pulse, XXVI (October, 1925), 26.

1926

“Old Ironsides," The Pulse, XXVI (February, 1926), 7.

"The New Bank Building," The Pulse, XXVI (May, 1926), 2.

1927

"Prairie Spell," "Poet of the Wapsipinicon," The Pulse, XXVII (February, 1927), 4, 7 .

"A Gift of Laughter," The Pulse, XXVII (April, 1927), 4.

"Soliloquy of a Farmer," The Pulse, XXVII (May, 1927), 8-9.

[Received fourth place in National High School Poetry Contest.]

1928

"Prairie Winds (Chiefly the Sounds They Bring): Debt, A Stream," The Caravan, II (May, 1928), 9-10. [From a group of poems winning third prize in the Ladies' Literary Club Contest.]

\section{9}

"Spirit of Beauty: I; II, Prayer to the Spirit of Beauty," "Eternal Earth: I. Earth; II. The Mist That Hides the River," "The Price of Corn," The Caravan, III (January, 1929), 3, 14, 23.

"Possession," The Tanager, IV (March, 1929), 112.

"Two Sonnets: The Golden House, Sounds of Earth," The Forge, IV (Spring, 1929), 68.

"Better Than Granite [10 sonnets]," "Dusty Laughter: I, The Second Coming," The Caravan, III (May, 1929), 3-7, 24.

"Greece and the Bloodroot, I-III," JAPM, II (May 20, 1929), 7-8.

"Better Than Granite," "The Golden House," "The Sound of Earth," "Dusty Laughter: I. The Second Coming," The Cedar Rapids Gazette and Republican (June 7, 1929), 2.

"The Second Coming," The Literary Digest, CI (June 15, 1929), 29.

"Peace for the Dead," The Lyric, IX (October, 1929), 1.

"Men Who Die: Paralytic," “The Breath of Being," The Forge, IV (Fall, 1929), 125.

"Flutter of Lips," The Harp, V (November-December, 1929), 11.

"Leaves for the Dead," Contemporary Verse, XXV (December, 1929).

\section{0}

"Midnight," "For Two Friends," "Gregory Gray," "The Son of God: I. Christ and Cancer; II. Salvation: Ten Cents," "A Reed in the Wind," The Caravan, III (January, 1930), 6, 18-20.

“Dust," The Kaleidoscope, I (April, 1930), 3.

"Steps in the Snow," Plain Talk, VII (July, 1930), 33.

"Two Poems: Hands of a Dead Machinist, To No Dark House," The Midland, XVI (September-October, 1930), 258. 
"Two Poems: Girl of Wind, Turret Lathe," Poetry, XXXVII (November, 1930), 78-80.

"Railroad Wives: I. No Clearance, II. The Way It Goes," Bozart and Contemporary Verse, IV (November-December, 1930), 14.

1931

"Shorty," The Tanager, VI (January, 1931), 58.

"A Fugitive in the Earth," "Society and Moonlight," "Thomas Hardy at Midnight," "Old Moonlight in a Shell," The Caravan, V (February, 1931), $7,10,19-21$, inside back cover [i.e. 25].

"Two Preludes (In Memory of Miss Emma Fordyce)," The Cedar Rapids Sunday Gazette and Republican (March 15, 1931), 3.

“No Stranger Place," The Saturday Review of Literature, VII (March 28, 1931), 689. [Awarded first prize in poetry division of Ladies' Literary Club contest in 1931.]

"Rabelais among the Ghosts," "Even a Sparrow's Fall," "Wind," The Caravan, V (May, 1931), 9, 21.

“Elegy," Poetry, XXXIX (October, 1931), 13.

1932

"Elegy for a Shy Lady," The New Republic, LXXII (September 14, 1932), 116. Also in The Husk, XIV (October, 1934), 16.

1933

"Lost Things," Poetry, XLI (March, 1933), 314-315.

"America Remembers," Poetry, XLII (June, 1933), 121-129. [Winner of prize given by the Friday Club of Chicago for a poem interpretative of the Century of Progress.] Also the closing lines of "America Remembers" in The Literary Digest, CXV (June 10, 1933), 33.

1934

"Wind-Flower," The Literary Arts, I (February-March, 1934), 13.

"New Times on the Plains," "The Last Cup," "Letter to Sam," "Burning My Boyhood's Poems," "Earth in Our Blood," Poetry, XLIV (May, 1934), 86-91.

"Luther Brewer," The Saturday Review of Literature, X (June 23, 1934), 762.

"America Remembers" (excerpt), "American Song" (excerpt), "Mary," Scholastic, XXV (November 3, 1934), 13.

1935

"Signature of Spring," The New Oxford Outlook, II (January, 1935), 137-138.

"Prologue," The North American Review, CCXL (September, 1935), 225237.

"New Poems: Russia; Vilna," American Prefaces, I (November, 1935), 26-27.

"Belleau Wood," The New Oxford Outlook, II (November, 1935), 242-249. 
“No Gull's Wings: O. E. Rolvaag (1876-1931)," American Prefaces, I (April, 1936), cover [i.e. 97].

“For A. E. Housman," Ladies' Home Journal, LIII (September, 1936), 71.

"Canterbury," Amevican Prefaces, II (December, 1936), 40-43.

"Maxim Gorky," New Masses, XXII (December 29, 1936), 19.

1937

"For Gabe's Seventieth Birthday," American Prefaces, III (October, 1937), 11.

"For Jay G. Sigmund," The Cedar Rapids Gazette (October 21, 1937), 17. 1938

"A Portfolio of Poems: February, Farmer, To You, Heritage, Return in Autumn, Familiar Change," American Prefaces, IV (December, 1938), 41-45.

"For 1939," American Prefaces, IV (January, 1939), 56-57.

"The Bones of the Buffalo," The Forum and Century, CI (January, 1939), 31. [First Prize, Forum poetry contest.]

"To Mary," The Saturday Review of Literature, XIX (January 14, 1939), 13.

"February," The Atlantic Monthly, CLXIII (February, 1939), 258.

"Homage to Robert Frost," "For An Apple-Grower," American Prefaces, IV (April, 1939), cover [i.e., 97], 105-107.

"In Training," The Saturday Review of Literature, XX (June 24, 1939), 8. "In Time of Crisis," Harper's Magazine, CLXXIX (August, 1939), 281. "The Old Way," The American Mercury, XLVIII (October, 1939), 190.

"Words for a Season," The Saturday Review of Literature, XX (October 7, 1939), 4.

"Windy Night," The Virginia Quarterly Review, XV (October, 1939), 649.

"Mary," Ladies' Home Journal, LVI (December, 1939), 66.

“Jay G. Sigmund," American Prefaces, V (December, 1939), 38.

"Our Human Strength: Extreme, Weather, Divination, Moving In, Bird, Fern, Our Human Strength," Poetry, LV (December, 1939), 115-121.

1940

“Pair," Ladies' Home Journal, LVII (January, 1940), 61.

"This Wearing Rough," Ladies' Home Journal, LVII (February, 1940), 45.

"Four Elms," The New Yorker, XVI (April 6, 1940), 50.

"R.W.E.," The Atlantic Monthly, CLXV (June, 1940), 797.

"February," "To You," "Familiar Change," American Prefaces, V (June,

1940), 165-166. (Reprinted from December 1938 issue.)

"Against the Night," Ladies' Home Journal, LVII (July, 1940), 102.

"A Shared Thing," Ladies' Home Journal, LVII (October, 1940), 105.

"That Continent," American Prefaces, VI (Autumn, 1940), 48-50.

"Woman and Man," The American Mercury, LI (November, 1940), 334. 
"Twenty Below," The Saturday Review of Literature, XXIII (January 4, 1941), 8.

“American Harvest," Life, XI (September 22, 1941), 68-72.

"America 1941: America 1941, On the Birth of My Child, Elements, Henry David Thoreau, Emily Dickinson, Contrary, Letter after Drouth," Poetry, LVIII (September, 1941), 293-301.

\section{3}

"Song for These States," The Step Ladder, XXX (March, 1943), 35.

[Winner of $\$ 100$ prize, Patriotic Song Contest. Copyright 1943 by Flora W. Seymour.]

\section{4}

"Cuban Voyage," The Kenyon Review, VI (Spring, 1944), 196-197.

"Let the Dead Go," Living Poetry, II (Autumn, 1944), 10.

"For An Aviator Killed Over Germany," The Saturday Review of Literature, XXVII (November 18, 1944), 22.

“American Child: 1," Ladies' Home Journal, LXI (November, 1944), 56.

“American Child: 2," Ladies' Home Journal, LXI (December, 1944), 58. 1945

“American Child: 3," Ladies' Home Journal, LXII (January, 1945), 89.

"American Child-II," The Kenyon Review, VII (Spring, 1945), 232-234. (5 sonnets)

“American Child-III," Poetry, LXVI (April, 1945), 1-7. (Sonnets 1-10.)

"American Child-IV," Rocky Mountain Review, IX (Summer, 1945), 177179. (5 sonnets)

"American Child," The Saturday Review of Literature, XXVIII (September 29, 1945), 12. (1 sonnet)

"For the Midwestern Dead [Sonnets IV, XII, VII]," Mademoiselle, XXI (September, 1945), 158-159.

"American Child," [selections] Senior Scholastic, XLVII (December 3, 1945), 19.

"American Child: Selections," Life, XXI (September 23, 1946), 73-74, 76. Octave of Sonnet XL reprinted in The Anamosa Journal (September 19, 1946), 1.

1950

"Three poems: Night Scene, Fossil, Beasts," Poetry, LXXVII (November, 1950), 63-68.

1952

“USA," Poetry, LXXXI (October, 1952), 35-36.

1953

"Lucky the Living Child, Born in a Land," The Des Moines Sunday Register Picture Magazine (July 12, 1953), 4.

1955

“A Willow Child," Ladies' Home Journal, LXXII (July, 1955), 94.

[20] 
“Two Poems: Amagansett Beach, Sick," Poetry, LXXXVI (August, 1955), 273-274.

“Map," Good Housekeeping, CXLI (September, 1955), 103.

“I'm Home," Ladies' Home Journal, LXXII (September, 1955), 160.

"Cowboy," Good Housekeeping, CXLI (November, 1955), 46.

"Montauk Wreck," "Face to Face," Botteghe Oscure, No. 16 (1955), 279 282.

1956

"Worm," Good Housekeeping, CXLII (February, 1956), 44.

"Don't Go," Good Housekeeping, CXLII (April, 1956), 18.

"River Daughter," The New Yorker, XXXII (May 19, 1956), 111.

“On This Wall, in This Town, in Their Own State; Paul Engle's Memorial Sonnets Salute the War Dead of Iowa," Life, XL (May 28, 1956), 95$96,99-100,105$.

"For the Iowa Dead [Sonnets I, II, III, XI, XII, and XXII]," The Iowa Alumni Review, IX (June, 1956), 2, 12-13.

"For the Iowa Dead," [four sonnets] The Iowan, IV (June-July, 1956), 24-25.

"Colette," Poetry, LXXXVIII (August, 1956), 321-323.

"From 'Dedication' in Break the Heart's Anger," The ILA Catalyst, X (October, 1956), 1.

"Book and Child: Three Sonnets," The New York Times Book Review: Children's Book Section, Part 2, LXV (November 18, 1956), 1.

"Three Sonnets for Colette," The Sewanee Review, LXIV (Winter, 1956), 128-129.

1957

“A Name,” Mademoiselle, XLIV (April, 1957), 172.

"In Flaming Silke: Jamestown," The Virginia Quarterly Review, XXXIII (Autumn, 1957), 505-506.

"For the Iowa Dead" [Sonnets I-XIII], Botteghe Oscure, No. 19 (1957), 219-225.

"Song of the Cedar," The Des Moines Sunday Register (November 3, 1957), 16. Also in The Iowan, VI (February-March, 1958), 20.

1958

"The Sound of Green," Ladies' Home Journal, LXXV (March, 1958), 188.

“An Old Palestinian Donkey," Better Homes and Gardens, XXXVI (April, 1958), 8.

"William Carlos Williams, M.D., For His Seventy-fifth Birthday on Sept. 17," The New York Times Book Review (September 14, 1958), 4.

1959

"A Gift of Song," Good Housekeeping, CXLVIII (March, 1959), 44.

"William Carlos Williams, M.D.,"Horizon, I (March, 1959), 60-61.

"To Praise A Man," [excerpts] Life, XLVI (June 15, 1959), 65-66.

"The Last Whiskey Cup," [selections] "Sonnet V from American Child,"

[21] 
"Sonnet III from For the Iowa Dead," Iowa English Yearbook (Fall, 1959), 4-5.

“To Be A Child," Ladies' Home Journal, LXXVI (October, 1959), 115.

"A Dedication," “The Sound of Red," Poetry, XCV (October, 1959), 27-28. "William Carlos Williams, M.D.," [excerpt] The Des Moines Sunday Register (November 8, 1959), 16-G.

"A Christmas Child," Better Homes and Gardens, XXXVII (December, 1959), 10.

"Western Child," Third Act of Opera by Philip Bezanson, Libretto by Paul Engle, The Des Moines Sunday Register Picture Magazine (December 20, 1959), 7-10.

\section{0}

"Always the Women," Ladies" Home Journal, LXXVII (January, 1960), 18.

"Easter," Better Homes and Gardens, XXXVIII (April, 1960), 35.

"What is a Child?" This Week Magazine (July 31, 1960), 2.

"You Can't Be Wise," The Kansas City Times (November 16, 1960), 32.

1961

"Christmas Poems: I. The Holly; II. The Wreath; III. The Lights; IV. The Tree; V. The Star; VI. The Animals; VII. The Lamb; VIII. The Wise Men; IX. The Glory of the Lord," The Des Moines Register (December 17-25, 1961), 1.

1962

"Ballet Rehearsal," The New Yorker, XXXVIII (March 17, 1962), 172.

"Letter About Love," Ladies' Home Journal, LXXIX (July, 1962), 22.

"Blind Man," Focus/Midwest, I (October, 1962), 9.

"Hercules (Drawing a Bow)," "Etruscan Vase in Form of a Cock," "Venus and the Lute Player (Tiziano Vecellio, 1477-1576)," Poetry, CI (October-November, 1962), 38-39.

1963

" "To Be a Poet, Be a Man'-To Edmund Blunden on His 65th Birthday," Life, International, XXXIV (April 22, 1963), 78-79. Selections in The Times (London) (June 24, 1965), 15.

\section{4}

"The Ending," The New Yorker (August 1, 1964), 34.

"Edmund Blunden," The Texas Quarterly, VII (Summer, 1964), 111-118.

"A Woman Talking: Encounter, Shadow, Garden, Lightning, Variations," Harper's Bazaar, XCVII (October, 1964), 241, 273.

"The Word and the Poet," Saturday Review, XLVII (December 12, 1964), 40.

"In a Bar Near Shibuya Station, Tokyo," "Taichung, Taiwan, Republic of China," Poetry, CV (December, 1964), 185-187.

1965

“Runaway," Ladies' Home Journal, LXXXII (January, 1965), 20. 
“A Prairie Episode,” The Pulse, XXVII (February, 1927), 5-6.

"A Trip to Hades in a Ford: The Reminiscences and Adventures of Arthur Collins and Paul Engle, While Visiting the Underworld," "On Riding Horses," The Pulse, XXVII (April, 1927), 5-7.

"Allons! The Road," The Pulse, XXVII (May, 1927), 10-11.

1931

"Butterfly Girl," The Caravan, V (May, 1931), 14-16.

1932

"Futile Defiance," The Palimpsest, XIII (February, 1932), 55-73.

1935

"Modern Poetry-English and American: A Discussion Between Paul Engle and Cecil Day Lewis," The Listener (May 15, 1935), 852-854.

1936

"Home Thoughts from Abroad," Partisan Review \& Anvil, III (May, 1936), 8-9.

"Says Edward Was Sacrificed to Medieval Law and Politics: Ex-King Happier Living Own Life, Declares Paul Engle," The Cedar Rapids Gazette (December 13, 1936), 4.

\section{7}

"Poetry in a Machine Age," The English Journal, XXVI (June, 1937), 429439.

“James Hearst," American Prefaces, II (Summer, 1937), 164.

1938

"New English Poets," The English Journal, XXVII (February, 1938), 89101.

1939

“About Robert Frost," American Prefaces, IV (April, 1939), 100.

"The Poet and the Man, Preface to Memorial Volume of Jay Sigmund's Finest Prose and Poetry," The Cedar Rapids Gazette (November 19, 1939), 5 and 7. Reprinted in American Prefaces, V (December, 1939), 39-41 with the title: "The Man and the Poet."

1940

"The Source of Poetry," College English, I (March, 1940), 471-480; also in The English Journal, XXIX (March, 1940), 177-186.

1941

“The Midwest: Its Land and Its People," Progressive Education, XVIII (October, 1941), 288-290. [Includes excerpts from three poems.]

1942

"An Interview with Iowa's Paul Engle: The Poet Who Wrote 'American Song' Discusses His Life and Dislikes," by Robert Van Gelder, The New York Times Book Review (March 22, 1942), 2. 
"Saga of a Horseman: Charlie Williams Obscure Iowan Who Rivaled Leland Stanford, Bred the Two Finest Racing Stallions of His Time," Esquire, XXV (February, 1946), 78-80.

"Children, Atoms, and Books," National Parent-Teacher, XLI (September, 1946), 7-9.

"Can Writing Be Taught?, Jobs and Futures in Writing," Mademoiselle, XXIV (January, 1947), 201, 259-260.

"University Hopes That Iowa Will Lead Nation in Creative Writing," The Des Moines Sunday Register, (December 21, 1947), VI, 9-E.

"How Creative Writing Is Taught at University of Iowa Workshop," The Des Moines Sunday Register (December 27, 1947), 9-G.

1948

"A Home in a Free Country," Perfect Home (July, 1948), 3.

1949

"Five Years of Pulitzer Poets," College English, X (February, 1949), 237244. Also in The English Journal, XXXVIII (February, 1949), 59-66.

1950

"Revolution on Campus," Flair, I (August, 1950), 14-19, 91.

1952

"Poet and Professor Overture," [Introduction to collection of poems written by members of the Iowa workshop] Poetry, LXXIX (February, 1952), 267-270. 1953

"Why Modern Poetry," College English, XV (October, 1953), 7-11.

1955

"A Writer Is a Teacher Is a Writer: A Poet-Professor Discusses the University as a Creative Force," The New York Times Book Review, LX (July 17, 1955), 1, 14. Reprinted in The Des Moines Sunday Register (July 24, 1955), VII, 4, with title: "Engle Tells Why Writers Teach."

"Poetry, People and Pigs," The lowan, IV (October-November, 1955), 12. Reprinted in The Des Moines Register (October 20, 1955), 8, with the title: "Iowa City: In the Land of Pigs, People, Corn and Culture." [Text of one of a series entitled "Why I Like the Community in Which I Live," broadcast by the Voice of America.]

"Why Paul Engle Prepared Article on Arts at S.U.I.: Letter to the Editor," The Des Moines Register (November 15, 1955), 12.

\section{6}

"Iowa: The Heart of America's Heartland," Holiday, XX (October, 1956), 42-51, 89-90.

"Poetry Is Ordinary Language Raised to the Nth Power," The New York Times Book Review, LXII (February 17, 1957), 4.

“The Mighty Big Ten," Holiday, XXI (March, 1957), 62-71, 105, 108-109. 


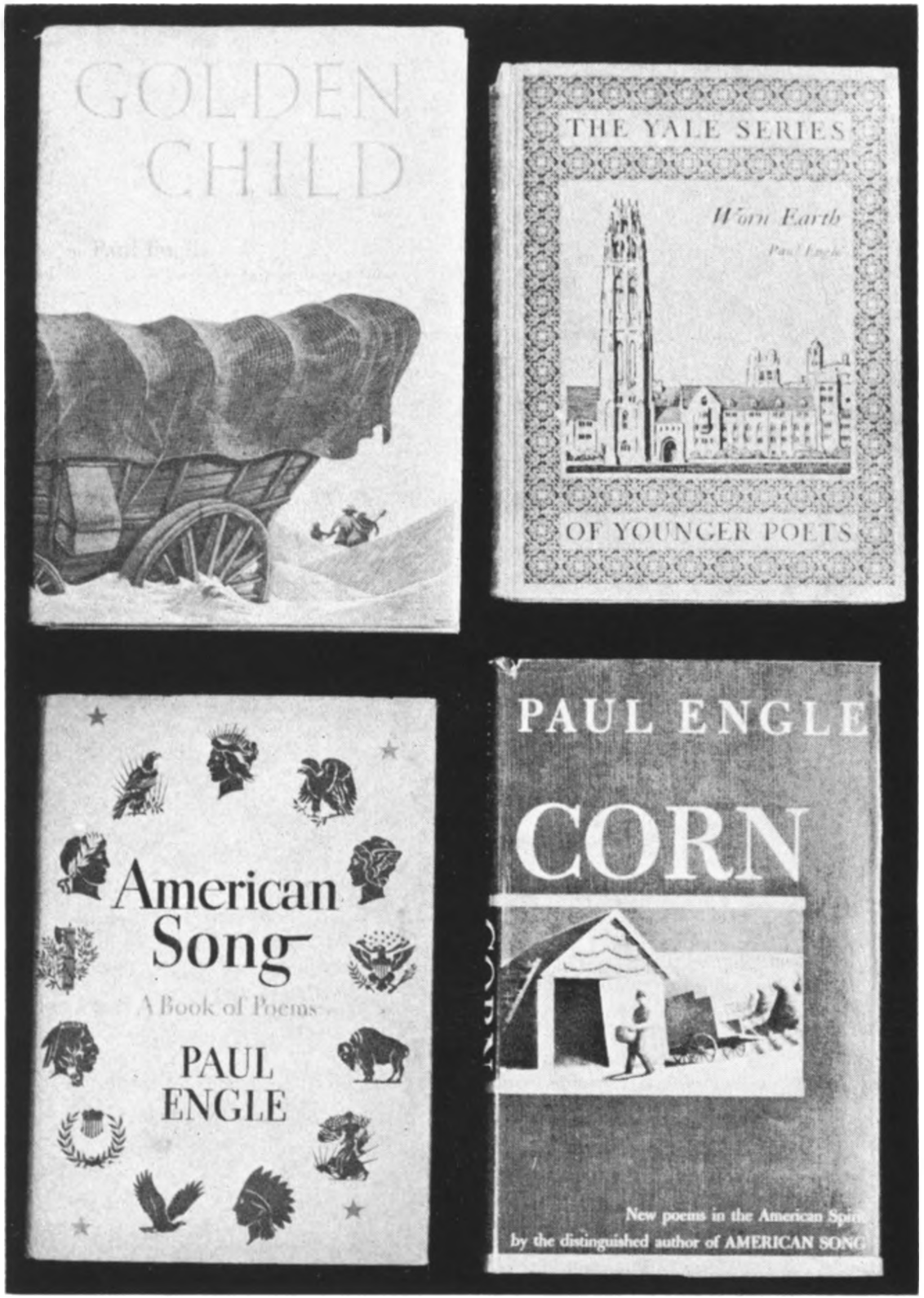

Four books by laul Lingle, from the Iowa Authors Collection. 
"An Iowa Christmas," American Heritage, IX (December, 1957), 16-21. Reprinted in The Cedar Rapids Gazette (December 15, 1957), Section II, 1-4. Condensed in Reader's Digest, LXXIII (December, 1958), 114117 with title: "An Old-Time Iowa Christmas."

\section{8}

"That Fabulous Old Fourth of July," Better Homes and Gardens, XXXVI (July, 1958), 38-39, 100. Reprinted in The Cedar Rapids Gazette (June 29, 1958), 12. Condensed in Reader's Digest, LXXV (July, 1959), 149. 150, 153-154, with title: "That Old-Time Fourth of July."

"This Was Our Christmas," Better Homes and Gardens, XXXVI (December, 1958), 37, 116, 118, 120.

\section{9}

"Remember Memorial Day!" Better Homes and Gardens, XXXVII (May, 1959), 38, 174-175.

"When It's Think Time in the Rockies," Holiday, XXVI (July, 1959), 54-55, 122-125.

"Poet's Tribute to Spunky Womenfolk," Life, XLVII (August 17, 1959), 73-76.

\section{0}

"In Defense of the State University," The Saturday Evening Post, CCXXXII (February 13, 1960), 22-23, 64-66.

“Grand Tour, USA," Mademoiselle, L (April, 1960), 160-162.

"Centennial Tour of the Civil War," Better Homes and Gardens, XXXVIII (October, 1960), 137-140, 143-145.

“Christmas: Our Mother's Hands," McCalls, LXXXVIII (December, 1960), 10. [Selection from Prairie Christmas]

"Old-Fashioned Christmas," Twelve Chapters in The Des Moines Register

(December 12, 1960), 1,8; (December 13, 1960), 1, 6; (December 14, 1960), 1, 12; (December 15, 1960), 1, 12; (December 16, 1960), 1, 4; (December 17, 1960), 1, 7; (December 19, 1960), 1, 6; (December 20, 1960), 6; (December 21, 1960), 5; (December 22, 1960), 4; (December 23, 1960), 5; (December 24, 1960), 1,7.

\section{1}

“An Age of Concentration," Reader's Digest, LXXVIII (March, 1961), [Inside front cover.]

“A Fine Place at a Crucial Time," St. Paul's Outlook, XXII (May 19, 1961), 1 .

\section{2}

"They Found Beauty, Peace in What Has Become Iowa; The Story of the White Man's First View of Iowa," The Des Moines Sunday Register (June 24, 1962), Local News Section, 1-L, 11-L.

"Poet on His Poem," by Paul Engle and Joseph Langland, Saturday Review, XLV (August 11, 1962), 12, 47. [Preprint of preface to Poet's Choice] 1963

"Shapers of Literature, Paul Engle." [Interviewed by R. W. Apple, Jr., of [29] 
NBC News.] The New York Herald Tribune Books, XXIX (May 12, 1963), 6. Reprinted in The Des Moines Register (May 24, 1963), 10. Also in American Oxonian, L (July, 1963), 144-148.

"Eastern Iowa Poet's Impression of Asia: SUI's Paul Engle Spends Five Months Talking Face to Face with Asian Writers," The Cedar Rapids Gazette (June 9, 1963), Section B., 1, 4.

\section{4}

"Salt Crystals, Spider Webs, and Words," Saturday Review, XLVII (March 14, 1964), 10-13.

"The Story of Kim," The New York Times Book Review (February 16, 1964), 35. Reprinted in The Daily Iowan (April 3, 1964), 2.

"Engle Replies to Friedlander Letter: Letter to the Editor," The Daily Iowan (March 5, 1964), 2.

"Engle Answers Critic [Miss Friedlander]: Letter to the Editor," The Daily lowan (April 3, 1964), 2.

"The Nourishing Place: An Abundant Land, a Sturdy People, Their Faith and Their Food Are Perfectly Joined in the Religious Community of Amana, Iowa," Venture, I (June, 1964), 92-95.

"Opinion, Please: From Iowa City," Mademoiselle, LIX (October, 1964), $34,42$.

"Home for Christmas," [reprinted from An Old Fashioned Christmas] Redbook, CXXIV (December, 1964), 35, 84.

\section{5}

"Liveliest Republican of Them All," The New York Times Magazine (April 4, 1965), 141-143.

"Wendell Johnson," The Iowa Alumni Review, XVIII (October, 1965), 13.

“Christmas Is People," McCall's, XCIII (December, 1965), 79-81, 160-161.

\section{6}

[Letter concerning horse sales in Cedar Rapids during World War I] The Cedar Rapids Gazette (March 20, 1966), 2C.

"Iowa's State Fair," Photographs by Dennis Stock, Holiday, XXXIX (May, 1966), 78-87.

“Should This Father Raise His Son? No," Ladies' Home Journal, LXXXIII (May, 1966), 89, 154, 156.

"Engle Praises Music Groups: Letter to the Editor," The Daily Iowan (May $24,1966), 2$.

\section{CONTRIBUTIONS TO ANTHOLOGIES OR BOOKS BY OTHER AUTHORS}

\section{Poems}

1928

"Prairie Winds (Chiefly the Sounds They Bring): Dawn Mist, Sunset Villanelle, The Price of Corn, Prairie Twilight, Debt, A Stream," "Question," “A Passing Automobile," “An Afterthought," “To a Lonely Dancer," 
"Advice," in Roland Kampmeier (editor with the assistance of others) Contemporaries! Current Forms of Composition from Laurence C. Woodman's Coe College Freshman English Classes, 1927-1928. With an Introduction by Jay G. Sigmund. (Vinton, Iowa: Kruse Publishing Co., 1928), 31-36, 41-42.

"I. A Vein for Silver and a Place for Gold," "II. Perchance to Dream," "Farmers at Sunset," in A First Book of Iowa Poets: Forty-nine Poems By Writers Who Are Now Living in the State (Des Moines: The Maizeland Press, 1928), 8-10.

\section{9}

"Greece and the Bloodroot," in William Stanley Braithwaite (editor) Anthology of Magazine Verse for 1929 and Yearbook of American Poetry (New York: George Sully \& Co., 1929), 102-103.

\section{1}

"Elegy for a Shy Lady," "Elegy in Spring," "One Slim Feather," "No Stranger Place," "I. To No Dark House," "II. Steps in the Snow," "III. Shorty," "IV. Turret Lathe," "V. The Way It Goes," in Paul Engle and Harold Cooper (editors) West of the Great Water: An Iowa Anthology (Iowa City, Iowa: Athens Press, 1931), 11, 21, 42-47.

"Girl of Wind," "Turret Lathe," "Steps in the Snow," "No Stranger Place," in Jessie Rehder (editor) Best College Verse: 1931, with a Preface by Christopher Morley (New York: Harper \& Brothers Publishers, 1931), 75-78.

\section{2}

“A Note on Names," in Harold Cooper, Edge O’Arden (n.p., n.pub., 1932) [p.i.].

\section{3}

"Lost Things," in Thomas Moult (editor) The Best Poems of 1933 (New York: Harcourt Brace \& Co., Inc., 1933), 100.

\section{5}

"The Last Whiskey Cup," in Walter Blair and W. K. Chandler (editors) Approaches to Poetry (New York: D. Appleton-Century Company, Inc., 1935), 756-757. Also in Second Edition (New York: Appleton-CenturyCrofts, Inc., 1953), 722-724.

"The Last Whiskey Cup," in The Great American Parade (Garden City, N.Y.: Doubleday, Doran \& Co., 1935), 377-379.

"Orion," in Alfred Kreymborg (editor) An Anthology of American Poetry: Lyric America, 1630-1930, including Supplement, 1930-1935. Revised Edition (New York: Tudor Publishing Co., 1935), 650-651. Also in Second Revised Edition (1941), 622-623 with the title: An Anthology of American Poetry: Lyric America, 1630-1941.

"Steps in the Snow," "Road Gang," "Society and Moonlight," "The Edge of Mind," "Flutter of Lips," in The House of Henry Harrison, Publishers (editor) Iowa Poets, An Anthology of 69 Contemporaries (New York, c1935), 66-68. 
"Introductory Essay," in Robert Frost, Selected Poems, chosen by the author; with Introductory Essays by W. H. Auden, C. Day Lewis, Paul Engle and Edwin Muir. (London: J. Cape, 1936)

1938

"Here by This Midland Lake [A short selection from "America Remembers']," in Selden Rodman (editor) A New Anthology of Modern Poetry (New York: Random House, 1938), 213-214. Also published by The Modern Library in 1939 and in Revised Edition (Modern Library, 1946) as "From America Remembers," 139-140.

"High on This Point of Rock," "This Mighty Needle" (selected from "The Troubadour of Eze") in Adolph Gillis and William Rose Benét (editors) Poems for Modern Youth (New York: Houghton Mifflin Co., 1938), 116-117.

"Maxim Gorky," in Alan F. Pater (editor) Anthology of Magazine Verse for 1937 and Yearbook of American Poetry (New York: The Paebar Co., Inc., 1938), 42.

1939

"Reproof to Death," in Anita P. Forbes (editor) Modern Verse, Revised, Book Two (New York: Henry Holt \& Co., 1939), 106.

1940

“Epilogue" written by Paul Engle for America Was Song and Laughter, a Musical Revue created by the Cornell Summer Theatre Troup . . . July 4, 5, 1940. [Mount Vernon, Iowa: Cornell College, 1940] (24-line poem on leaf 2 of a mimeographed program.)

"In Time of Crisis," in Thomas Moult (editor) The Best Poems of 1940 (New York: Harcourt Brace \& Co., [1940]), 39.

\section{1}

"Against the Night," in Harriet Marcelia Lucas (editor) Prose and Poetry of Today: Regional America (Syracuse, N.Y.: The L. W. Singer Co., 1941), 507-508.

"Cat's Eye," "No Gull's Wings," in Horace J. McNeil and Clarence Stratton (editors) Poems for a Machine Age (New York: McGraw-Hill Book Co., 1941), 161, 339. Also published by the Globe Book Co., Inc., 1949 with the title: Living Poetry.

1942

"February," "Emily Dickinson," in Alan F. Pater (editor) Anthology of Magazine Verse for 1938-1942 and Yearbook of American Poetry (New York: The Paebar Co., 1942), 144-145.

1943

"The Last Whiskey Cup," in Frank A. Russell (Ted Malone, pseud. editor) Yankee Doodles: A Book of American Verse (New York: Whittlesey House, McGraw-Hill Co., Inc., 1943), 94-96. Also published under the title: The All-American Book of Verse: Yankee Doodles (Garden City, N.Y.: Garden City Publishing Co., 1948) 
"Ancestral Iowa," in John T. Frederick (editor) Out of the Midwest: A Collection of Present-Day Writing (New York: Whittlesey House, McGraw-Hill Book Company, Inc., 1944), 352-353.

\section{5}

"America Remembers," in John T. Flanagan (editor) America Is West (Minneapolis: University of Minnesota Press, 1945), 664-672.

"Emily Dickinson," in Houston Peterson and William S. Lynch (editors) Poet to Poet: A Treasury of Golden Criticism (New York: Hall, Inc., 1945), 309.

"For an Apple Grower," in Lowry C. Wimberly (editor) Mid Country; Writings from the Heart of America, with an Introduction by B. A. Botkin (Lincoln: University of Nebraska Press, 1945), 67-70.

"From 'Prologue' to Break the Heart's Anger," in William Rose Benét and Norman Cousins (editors) The Poetry of Freedom (New York: Random House, 1945), 544-545. Also published by The Modern Library in 1948.

$$
1955
$$

"Beasts," "Fossil," "Cuban Voyage," in Paul Engle and Warren Carrier (editors) Reading Modern Poetry (Chicago: Scott, Foresman and Company, 1955), 233-238. Also as translator of Rainer Maria Rilke, "The Panther," "Remembrance," “Joseph's Suspicion," 421, 423-425.

\section{6}

"American Child, 1," in John Mason Brown and the Editors of the Ladies' Home Journal (editors) The Ladies' Home Journal Treasury (New York: Simon and Schuster, 1956), 293.

"Chameleon," in W. H. Auden (editor) The Criterion Book of Modern American Verse (New York: Criterion Books, 1956), 249-250.

\section{7}

"The Burial of Baudelaire: Montparnasse Cemetery, 1867," in Paul Engle (editor) Homage to Baudelaire, on the Centennial of Les Fleurs du Mal, from the Poets at the State University of Iowa (Iowa City, Iowa: The Cummington Press, 1957), 20-21.

"Song of the Cedar," in Sutherland Dows Seven Ages of a City, illustrated by Edwin J. Bruns, oil paintings and word pictures that give insight to Cedar Rapids history . . . [Cedar Rapids], (Iowa Electric Light and Power Company, c1957), page facing title page.

"If Everything," "USA," in Oscar Williams (editor) The Silver Treasury of Light Verse, from Geoffrey Chaucer to Ogden Nash (New York: The New American Library, 1957), 35, 48-49.

\section{8}

"For the Iowa Dead. [Sonnets I-III, X-XI, XIII]," in Best Poems of 1957: Borestone Mountain Awards, 1958; A compilation of Original Poetry Published in Magazines of the English-speaking World in 1957. The Tenth Annual Issue. (Stanford, Califormia: Stanford University Press, 1958), 35-37. 
"A Man," in Donald Justice (editor) West of Boston: Poems from the State University of lowa Poetry Workshop in Honor of the Visit of Robert Frost (Iowa City: The Qara Press, [1959]), [3-4].

1961

"From: Colette [Sonnets IV and VI]," in A Selection of SUI Writing (Iowa City, Iowa: The Daily Iowan, Supplement, March 29, 1961), [2].

"Edmund Blunden on His Sixty-fifth Birthday," in Chau Wah Ching, Lo King Man, Yung Kai Kin (editors) Edmund Blunden Sixty-five (Hong Kong: [English Society, University of Hong Kong] 1961), 88.

"The Word and the Poet," in Poems: All of them touching on some aspect of the imagination and written by members and former members of the University, some of them especially for the occasion, read as part of Creative Arts Week, May 1961, at The University of Iowa [Iowa City, 1961], [27-28].

"You Can't Be Wise," "From For the Iowa Dead, Sonnets XIII and XV," "Beasts," in Paul Engle (editor, assisted by Henri Coulette and Donald Justice) Midland: Twenty-five Years of Fiction and Poetry Selected from the Writing Workshops of the State University of Iowa (New York: Random House, 1961), 448-451.

1962

"Beasts," in Paul Engle and Joseph Langland (editors) Poet's Choice (New York: The Dial Press, 1962), 92-95.

"Beasts," "Sonnet LXXII from American Child," "Self-Portrait: Vincent Van Gogh," "The Count Duke of Olivares: Velasquez," "Venus and the Lute Player," "The English Dandy at the Moulin Rouge: Toulouse-Lautrec," "Fossil," "The Word and the Poet," in National Poetry Festival Held in the Library of Congress, October 22-24, 1962. Proceedings (Washington, D.C.: General Reference and Bibliography, Reference Department, Library of Congress, 1962), 205-211.

"To Praise a Poet: Robert Frost," in Walter Blair, Paul Farmer, Theodore Hornberger, and Margaret Wasson (compilers) The United States in Literature (Chicago: Scott, Foresman and Company, 1962), 551.

1964

"The Panther" of Rainer Maria Rilke, as translator, in Poems from XV Languages: Translated by Members of the Program in Creative Writing at The University of Iowa (Iowa City: The Stone Wall Press, 1964), 26.

\section{5}

“The Ending (Tokyo: A Woman Speaks)," in Best Poems of 1964: Borestone Mountain Poetry Awards, 1965; A Compilation of Original Poetry Published in Magazines of the English-speaking World in 1964, Volume XVII (Palo Alto, California: Pacific Books, Publishers, 1965), 48-49.

"For Two Children," translation of "A deux enfants" by René Char, "Eternity at Lourmarin," translation of "L'Eternite a Lourmarin: Albert Camus" by René Char, as translator, in Alexandre Aspel and Donald Justice 
(editors) Contemporary French Poetry: Fourteen Witnesses of Man's Fate (Ann Arbor: University of Michigan Press, 1965), 79, 81, 83.

\section{Prose}

1928

"The Faith of a Freshman," in Roland Kampmeier (editor with the assistance of others) Contemporaries! Current Forms of Composition from Laurence C. Woodman's Coe College Freshman English Classes, 19271928. With an Introduction by Jay G. Sigmund (Vinton, Iowa: Kruse Publishing Co., 1928), 36-41.

$$
1939
$$

"Introduction," in Herbert Krause, Neighbor Boy, Illustrations by Cyrus Running (Iowa City, Iowa: Midland House, Publishers, 1939), 7-12.

1942

"Ford Maddox Ford," in James Laughlin (editor) New Directions, 1942, VII (Norfolk, Connecticut: New Directions Press, 1942), 471-472.

\section{1}

"Foreword," in Poems from the Iowa Poetry Workshop (Iowa City, Iowa: The Prairie Press, 1951) [5-6] (450 copies)

1952

"The Creative Person in a World of Conflict," in Charles M. Allen and J. Lloyd Trump (editors) Education During World Transition; the Proceedings of the Illinois Summer Educational Conference, 1951 (Urbana, Illinois: University of Illinois, 1952), 31-40.

\section{8}

"The Gulf Is Always Thirsty," in The Centennial Celebration of Baudelaire's Les Fleurs du Mal (Austin, Texas: University of Texas Press, 1958), 3-12.

$$
1960
$$

"Portrait of the Artist as Neighbor," in Marvin Cone: A Retrospective Exhibit [A catalogue] (Iowa City, Iowa: Department of Art, School of Fine Arts, The University of Iowa, 1960 [2-3].

1963

"The Prairie and Plains," Chapter V, in Alvin M. Josephy, Jr. (editor in charge) The American Heritage Book of Natural Wonders (New York: Published by the American Heritage Publishing Company, distributed by Simon and Schuster, Inc., 1963), 153-210.

"Why Modern Poetry?" in Walter Blair, Paul Farmer, Theodore Hornberger and Margaret Wasson (compilers) The United States in Literature (Chicago: Scott, Foresman \& Company, 1963), 540-551.

\section{4}

"Preface," in Poems from XV Languages, Translated by Members of the Programs in Creative Writing at The University of lowa (Iowa City, Iowa: The Stone Wall Press, 1964), 3-4.

"The Breadbasket" [including an essay on "The Hartfords"], Chapter 6, in 
The American Heritage Cookbook and Illustrated History of American Eating \& Drinking (New York: Distributed by Simon and Schuster, Inc., 1964), 195-214.

\section{5}

"Postface," in Alexandre Aspel and Donald Justice (editors) Contemporary French Poetry: Fourteen Witnesses of Man's Fate [a bilingual edition] (Ann Arbor, Michigan: University of Michigan Press, 1965), 190-194.

\section{WORKS EDITED BY PAUL ENGLE}

THE PULSE, School Magazine of Washington High School, Cedar Rapids, Iowa. Volume XXVII, October \& December, 1926, February, April \& May, 1927. Paul Engle and Louise Northcott, Editors-in-Chief.

THE CARAVAN. Published by the Writer's Club of Coe College, Cedar

Rapids, Iowa. Volume III, May 1929. Edna Eckel, Editor-in-Chief; Paul Engle, Assistant Editor.

WEST OF THE GREAT WATER: an Iowa Anthology. Paul Engle and Harold Cooper (editors). With a Preface by Norman Foerster. Iowa City, Iowa: Athens Press, n.d. [1931].

THE NEW OXFORD OUTLOOK. Oxford: Basil Blackwell, Volume II, November 1935, edited by Richard Crossman-Paul Engle-Gilbert Highet.

AMERICAN PREFACES: A Journal of Critical and Imaginative Writing. Iowa City: University of Iowa Press. Volume II, No. 2 (November, 1936) -Volume V, No. 10 (Summer 1940), edited by Wilbur L. Schramm with the assistance of Paul Engle and others; Volume VI, No. 1 (Autumn 1940)-Volume VII, No. 1 (Autumn 1941), edited by Wilbur Schramm and Paul Engle; Volume VII, No. 2 (Winter 1942) - Volume VIII, No. 3 (Summer 1943) edited by Paul Engle and others.

OZARK ANTHOLOGY, by G. F. Newburger. Paul Engle, editor. Cedar Rapids, Iowa: The Torch Press, 1938. "Preface" (p. 7-13) by Paul Engle. SELECT POETRY AND PROSE, by Jay G. Sigmund. Edited by Paul Engle. Muscatine, Iowa: The Prairie Press, 1939. "Introduction" (p. i-ix) and poem "Jay G. Sigmund" (p. xii-xiii) by Paul Engle. (550 copies)

THE WESTERN REVIEW: A Literary Quarterly Published at the State University of Iowa. Volume XIV, No. 1 (Autumn 1949)-Volume XXI, No. 4 (Summer 1957), edited by Ray B. West, Jr.; advisory editor, Paul Engle.

PRIZE STORIES OF 1954: The O. Henry Awards. Selected and edited by Paul Engle and Hansford Martin. Garden City, N.Y.: Doubleday \& Company, Inc., 1954. "Introduction" (p. 11-17) by the editors.

PRIZE STORIES OF 1955: The O. Henry Awards. Selected and edited by Paul Engle and Hansford Martin. Garden City, N.Y.: Doubleday \& Company, Inc., 1955. "Introduction" (p. 9-12) by the editors.

READING MODERN POETRY. Paul Engle and Warren Carrier (editors). Chicago: Scott, Foresman and Company, 1955. Includes a preface in- 
itialed by both editors and analyses by Paul Engle of Sandburg"s "To the Ghost of John Milton" and of Eliot's "The Love Song of J. Alfred Prufrock."

PRIZE STORIES OF 1956: The O. Henry Awards. Selected and edited by Paul Engle and Hansford Martin. Garden City, N.Y.: Doubleday \& Company, Inc., 1956.

PRIZE STORIES OF 1957: The O. Henry Awards. Selected and edited by Paul Engle, assisted by Constance Urdang. Garden City, N.Y.: Doubleday \& Company, Inc., 1957. "Introduction" (p. 8-12) by Paul Engle.

HOMAGE TO BAUDELAIRE: On the centennial of Les Fleurs du Mal, from the poets at the State University of Iowa. (Iowa City, Iowa: The Cummington Press, 1957). 25 p. (475 copies) "The Poet," p. 5-6.

PRIZE STORIES OF 1958: The O. Henry Awards. Selected and edited by Paul Engle, assisted by Curt Harnack. Garden City, N.Y.: Doubleday \& Company, Inc., 1958. "Introduction" (p. 7-10) by Paul Engle and Curt Harnack.

PRIZE STORIES OF 1959: The O. Henry Awards. Selected and edited by Paul Engle, assisted by Curt Harnack and Constance Urdang. Garden City, N.Y.: Doubleday \& Company, Inc., 1959. "Introduction" (p. 9-12) by Paul Engle.

MIDLAND: Twenty-five Years of Fiction and Poetry. Selected from the Writing Workshops of the State University of Iowa. Edited by Paul Engle, assisted by Henri Coulette and Donald Justice. New York: Random House, 1961. "Introduction: The Writer and the Place" (p. xxi-xxxvii) by Paul Engle.

POET'S CHOICE. Paul Engle and Joseph Langland (editors). New York: Dial Press, 1962. “The Poet on His Poem" (p. xiii-xvii) signed by both editors.

ON CREATIVE WRITING. Edited by Paul Engle. New York: E. P. Dutton \& Co., Inc., 1964. "A Warning to the Reader" (p. xi-xii) and "The Writer on Writing” (p. 3-12) by Paul Engle. 